\title{
The Impact of the Alienation on the Artistic Expression Symbols of Homeless Egyptian Children
}

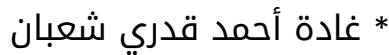 \\ * الدارسة بمرحلة الماجستير، بقسم علوم التربية الفنية، كلية التربية الفنية، جامعة حلوان. \\ البريد الإليكتروني: jodykadry2@hotmail.com \\ - ت تاريخ تسليم البحث الكامل للمجلة: 25 مايو 2021 - \\ - تاريخ موافقة هيئة التحرير على النشر: 12 يونيو 2021 تائ
}

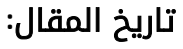

The Egyptian child at risk, especially (homeless children), lacks in his artistic expression الملخص: belonging to his Egyptian culture despite his high intelligence and observation power that exceeds the normal child with sound living conditions, and this is also what was concluded through the workshops. We find that alienation controls a lot of ideas and actions now, so the concept of alienation has become common and is the result of different visions and separation from others and the transformation person into a state of personal privacy that he must see reflected in his life, and in contemporary artistic works and discovered that it does not meet his reality as he wishes and dreams to He sees it. 
بحوث في التربية الفنية والفنون، المجلد (21)، العدد 3

\section{INTRODUCTION:}

According to Schiller, society is torn between two extremes: impotent rational planning and blind emotional action, In order to allow the boldness of emotion to execute reason's plan, society has to be free from the rigidity of reason as well as from the fluidity of emotion. Society needs an educator to teach it how to gain such freedom. The artist is the person to lead this liberating transition because the artist can create objects - works of art-that allow for freedom of play between our cognitive forces. Reason and emotion, at first presented as types of personality (the savage and the barbarian) are later presented as two essential aspects of human behavior : the sensuous drive and the formal drive.

The experience of beauty leads to a freedom of play of the faculties, at once releasing the subject from the tyranny of either extreme, and harmonising the two contrasting forces into one force

All interacting parties in the art education system are responsible for making textile assets for this education. Possible changes will make tomorrow's education required to confirm a number of key skills such as resilience, flexibility and the ability to deal with rapid change with the accompanying ambiguity and lack of clarity, and even chaos in Their interconnectedness, interdependence and ability to anticipate change, prepare for it and prepare to influence it, and the entrance to this should be supported by literacy of information, technologies, tools, arts and technology, and it should be supported by life and academic experience.

Therefore, the interest of social institutions to protect children without shelter because of the artistic side of them is an axiom in the aspect of modifying behavior, but what this technical aspect lacks is belonging to and rooted in the Egyptian identity, so we find that alienation controls many ideas and actions now, so the concept of alienation has become common and resulting From the difference of visions and separation from others and the transformation of person into a state of personal privacy that he must see reflected in his life, and in contemporary art works and discovered that it does not meet his reality as he would like and dreams to see

Through the work of the researcher in one of the institutions of caring for children in need of care and her participation in a project related to the artistic expression of children, "The hexagonal project The Interdependence Hexagon Project, which aims to: Reassess social and global challenges facing the world today and use art as a way to re-imagine how these challenges can be addressed Through critical thinking, research and creative expression. "

There were types of alienation in the symbols of the homeless child, expressive in artistic production, so if the child became acquainted with a culture of human rights and see some Egyptian symbol, he will be more alienated or more rooted in the culture of his country in his visual and intellectual vocabulary in the artistic expression of homeless children?

\section{Some of Egyptian art works for Children in need}

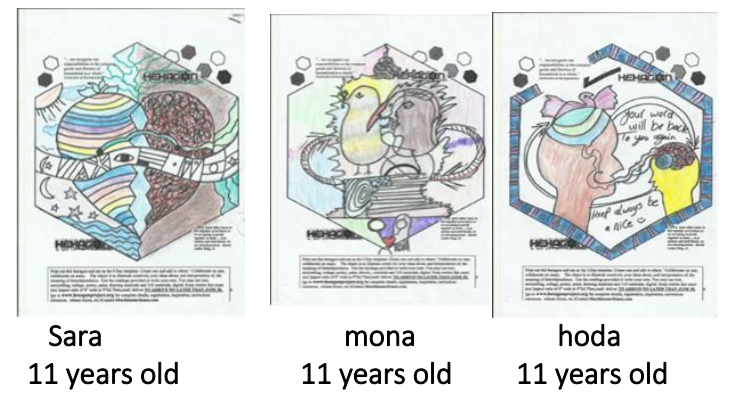

It is noted in these works that the influence of Western culture on children in the use of some foreign expressions and some non-Egyptian symbols, as well as insufficient clarity of the idea in artistic expression.

In Sara's Artwork she was trying to draw her peace feeling, So she draw her heart Divided by two parts of the world

In Mona's Artwork she also trying to draw the peace by drawing Dove of peace with different character In Hoda's Artwork she was trying to talk about the effect of the word you say to the others, that the word has a powerful effect

\section{Methodology:}

Studies that dealt with alienation in children's artistic expression, whether from a theoretical or practical side, included a group of books, scientific dissertations (MA - PhD), and research articles (refereed, and non-refereed).

Chronological studies, the study identified related studies in the early twentieth century, and was classified into models of studies that dealt with the 
بحوث في التربية الفنية والفنون، المجلد (21)، العدد 3

alienation in artistic expression as a theoretical concept, studies, and scientific dissertations (MA $\mathrm{PhD}$ ) as an applied aspect.

Geographically related studies inside and outside Egypt on the concept of alienation and studies for homeless children, in addition to the presence of some scientific articles and books that dealt with the concept of artistic alienation. The scientific messages on the concept of alienation and the concept of homeless children were mostly from the central libraries of Egyptian universities (Helwan - Fayoum). -The research relies on the descriptive and experimental approach, as it is divided into two frameworks:

\section{Theoretical framework:}

1) The culture of alienation, its causes and types.

2) Artistic expression for homeless children. Practical experience on homeless children inside homeless childcare institutions and the following procedures will be followed:

1) An artistic expression for homeless children.

2) Analysis of the visual and intellectual vocabulary of children's artistic expression according to the type of alienation

\section{Associated studies:}

\section{Ayman Abbas Al-Koumi's study (2001)}

This study dealt with the variables related to the problem of homeless children and the relationship between them. The study included various studies on the occupational, economic and health variables of the family and the correlation of these variables with the psychological and social compatibility of homeless children. The study was applied to a total of 300 children.

\section{Results :}

-There is a correlation between psychological variables and the problems of homeless children

-There is a link between the economic, health and educational variables and the problems of homeless children

\section{Rouff Lisa (2001)}

The study examined the relationship between the personality traits of homeless children, especially introversion, as a main feature of homeless adolescents, and between their association and their susceptibility to treatment. This experiment was carried out on 125 of the average age of 12 years.

\section{Results}

1) There is a large personal disturbance recorded by the introverted Muqabas

2) Introverted behavior was linked to a child's history of street exposure and homelessness

\section{Debar's study (2004)}

This study dealt with identifying the educational needs of street children through awareness of their environmental needs and methods of knowledge transfer.

\section{Results}

There are positive indications regarding children joining educational institutions for street children

\section{Rasha Hegazy study, 2009}

This study examined the effect of museum visits on developing the artistic taste of homeless children and to what extent there are differences between artistic appreciation and the growth of the artistic vision of children and the growth of aesthetic education, in which I emphasized the importance of museum visits for homeless children.

\section{Results}

-There are statistically significant differences between the average artistic taste scores in the growth of artistic vision among homeless children -There are differences between the average degree of artistic appreciation in the development of aesthetic education among children

\section{Study of Muhammad Hassan Jaber}

An analytical descriptive study that talked about alienation in general and then about cultural alienation. He also talked about the relationship between the self and the other, as the most important basis for understanding the phenomenon of alienation as a process and as a result. He also mentioned that the most important dimensions that complete the picture for understanding alienation are: awareness, positioning, or exodus, knowledge and meaning.

\section{Result}

Provide opportunities for individuals to freely express their opinions and rights.

- Building common value, reference and ideological foundations that are not based on interest. 
بحوث في التربية الفنية والفنون، المجلد (21)، العدد 3

\section{Gap analysis:}

The previous related studies dealt with the concept of alienation and the concept of homeless children through the presentation of some drawings that include the transmission of the concept of alienation, its measurement and knowledge of its dimensions. A gap was found between the previous studies, as previous studies did not study the effect of alienation within the symbols of the artworks of homeless children. Although previous studies stemmed from specialized colleges, studying the social, family and economic conditions of homeless children

\section{research importance:}

- Adding a classification of alienation in the visual and intellectual vocabulary of homeless children

The phenomenon of alienation as a social phenomenon contains three aspects, which are represented in the cultural aspects, social aspects and personal aspects.

As for the alienation of the form of artwork, it has two parts: the first is the alienation of the artistic form, which is the alienation of the formal and aesthetic value, and the second is the alienation of expressive content, which is alienation of thought and content

The Egyptian child at risk, especially (homeless children), lacks in his artistic expression belonging to his Egyptian culture, despite enjoying high intelligence and observation power that exceeds the normal child with sound living conditions, and this is also what was concluded through the workshops

So if artistic education is mainly based on the aesthetic and creative growth of the learners, as this type of growth is reflected in their behavior when they issue their decisions in the choice and preference of formulas, in everything that frustrates them with elements, subject to the elements of beauty and artistic creativity, then this growth It requires practice and immersion in the practice of creative activity and the

\section{Recommendations:}

- The researcher recommends the need to pay attention to the rooting of intellectual content for homeless children

- The researcher recommends paying attention to educating homeless children in a way that suits the culture of their society

\section{References:}

\section{Arabic references}

1) Ayman Abbas Al-Koumi 2001 The relationship of some psychological, social and economic variables to the problem of street children, field study, PhD thesis, unpublished research, Institute of Higher Studies for Childhood, Ain Shams University

2) Muhammad Hassan, 2000, The Family and Its Problems, Dar Al-Nahda Al-Arabiya for Printing and Publishing, 1st floor, Beirut

3) Rasha Sobhi Mohamed Hegazy, 2009, The Impact of Museum Visits on the Development of Artistic Appreciation among Homeless Children, Journal of Modern Education Association, Second Year, Fifth Issue, Faculty of Education, Fayoum University

4) El Syed Ali Sheta, Human Alienation in Industrial Organizations, University Youth Foundation,Egypt, 1994

5) Lamia Mohamed Youssef El Mahdy, The effect of the phenomenon of cultural alienation in artistic expression for students of the Faculty of Art Education, PhD thesis, Faculty of Art Education, Helwan University, cairo, Egypt,2006, p. 116

6) Mahmoud Al-Basyouni, "Guidance in Art Education", Dar Al-Maaref, Cairo, Egypt,1993, pp. 815

\section{English references}

7) Anne.Mary (2000) : Philosophy of Education , Technology and Life, The ABCs, portfolio Home Page press, London, $\mathrm{P} 1$

8) Debar, Gamine (2004): E ducation Need of Homeless Children "Perception of Environment and Transportation, thesis (M. S.W) California State University. Masters Abstracts International, V, 43, N 0.2 .

9) Moore, R. (1994) Aesthetics for Young People: Problems and Prospects, Journal of Aesthetic Education, 28. 3, pp. 5- 18.

10)Parsons, M. J. and Blocker, H. G. (1993) Aesthetics and Education ( $\mathrm{C}$ hampaign, IL, University of Illinois Press).

11)Moore, R. (1993) Aesthetic Case Studies and Discipline-Based Art Education, Journal of Aesthetic Education, 27. 3, pp. 51-62

12)Rouff Lisa. 2001 "Schizoid personality traits Among the homeless Adolescents" Aquantitive \& Qualitative report, Journal of Social Distress \& The Homeless, Vol (9), No (2), pp. 127-141

13)https://www.hexagonproject.org/ 